\title{
FERMENTE GIDALARIN İNSAN SAĞLIĞI ÜZERİNDEKİ ETKİLERİ
}

\author{
Büşra Akdeniz Oktay ${ }^{*}$ Z. Yeşim Özbaş \\ Hacettepe Üniversitesi, Mühendislik Fakültesi, Gıda Mühendisliği Bölümü, Ankara, Türkiye
}

Geliş / Received: 07.09.2020; Kabul / Accepted: 16.11.2020; Online bask1 / Published online: 25.11.2020

Akdeniz Oktay, B., Özbaş, Z.Y. (2020). Fermente gıdaların insan sağlı̆̆ üzerindeki etkileri. GIDA (2020) 45(6) 1215-1226 doi: 10.15237/gida.GD20105

Akdeniz Oktay, B., Özbas, Z.Y. (2020). The effects of fermented foods on buman bealth. GIDA (2020) 45(6) 1215 1226 doi: $10.15237 /$ gida.GD20105

\section{ÖZ}

Tarihin eski dönemlerinde gıdaları fermente ederek kullanmanın amacı, gıda maddesini daha uzun süre saklayabilmek ya da gıdada çeşitli aroma maddelerini geliştirmek olarak tanımlanmaktadır. Sağık üzerindeki olumlu etkilerinin anlaşılmasıyla birlikte, fermente gidalar günümüzde sıklikla tüketilen gidalar haline gelmişlerdir. Fermente gıdalar, yararlı mikroorganizmaların katıldığı kontrollü prosesler ile, gıdaların fermantasyona uğraması sonucunda, çeşitli enzimatik değişimlerin ve sağlığa yararlı son ürünlerin meydana geldiği fonksiyonel gıdalar olarak tanımlanmaktadırlar. Fermantasyon sürecinde yer alan mikroorganizmalar, ürettikleri çeşitli metabolitler ve bunların insan sağlığı üzerindeki olumlu etkileri, birçok bilim dalının ilgisini çekmekte ve günümüzde halen, sıklıkla araştırılan konular arasında yer almaktadır. Bu derlemede, fermente ürünlerin ve probiyotik mikroorganizmaların çeşitli fonksiyonel özellikleri üzerinde durularak bunların, insan sağlığı üzerindeki olumlu etkileri ele alınmıştır.

Anahtar kelimeler: Fermente gıdalar, probiyotik, prebiyotik, bağırsak mikrobiyotası, kronik hastalıklar.

\section{THE EFFECTS OF FERMENTED FOODS ON HUMAN HEALTH}

\begin{abstract}
In ancient times, the purpose of the fermenting foods was identified as keeping the food material for a longer time or improving some aroma compounds in food. With understanding of the positive effects of fermented foods on human health, nowadays they are frequently consumed. Fermented foods are defined as functional foods which involve in controlled processes of beneficial microorganisms. As a result of fermentation, various enzymatic changes and healthful end products are formed. Microorganisms acting on fermentation, their several metabolites and positive effects on human health attract many disciplines and recently all are often investigated. In this review, by emphasizing the functional properties of fermented foods and probiotic microorganisms, their positive effects on human health are discussed.
\end{abstract}

Keywords: Fermented foods, probiotic, prebiotic, gut microbiota, chronic diseases.

\footnotetext{
${ }^{*}$ Yazışmalardan sorumlu yazar/Corresponding author:
}

$凶$ : busra.akdeniz@hacettepe.edu.tr $\quad 0:(+90) 3212977100$

息: (+90) 3122992123

Büşra Akdeniz Oktay; ORCID No: 0000-0002-9812-3126

Z. Yeşim Özbaş; ORCID No: 0000-0002-1189-800X 


\section{GİRİ̧̧}

Fermantasyonun; Latince'de kaynamak anlamına gelen Fervere kelimesinden türetildiği ifade edilmektedir (Asghar vd., 2017). Fermantasyon prosesi, gida maddelerinin uzun süre saklanabilmeleri amacıyla yapılan ya da kontrollü olarak gerçekleştirilen mikrobiyel bir süreç ile bir hammaddeden, farklı özellikte ürün oluşturmak amaciyla kullanılan, en eski ve ekonomik yöntemlerden birisi olarak kabul edilmektedir. Fermente edilmiş gidaların, normal gıdalardan daha farklı bazı özelliklere sahip olmaları nedeniyle, insan sağllğı üzerinde olumlu etkileri bulunmaktadır (Levent ve Cavuldak, 2017). Bunun yanı sıra fermente edilmiş ürünlerde tat, koku, kıvam gibi çeşitli organoleptik özelliklerin de geliştiği belirtilmektedir (Dimidi vd., 2019). Ayrica, fermantasyon süresince oluşan bakteriyosin, organik asit, etanol gibi çeşitli antimikrobiyel metabolitlerin de insan ve hayvan sağlığını olumsuz etkileyen çeşitli patojenlere etki ederek, gıdanın güvenilirliğini artırdığ1 da ifade edilmektedir (Demirgül ve Sağdıç, 2017).

\section{FERMANTASYON PROSESLERİ}

Fermantasyon prosesinin esas işlevi, NADH molekülünün, koenzim NAD’a dönüştürülerek glikoliz metabolizmasına dahil edilmesi ve oluşan pürivat molekülünden laktik asit yada etanol gibi son ürünlerin üretiminin sağlanmasıdır. Glikoliz sırasında oluşan pürivat molekülünün, farklı fermantasyon prosesleri ile farklı son ürünlere dönüştüğü ifade edilmiştir. (Aslam vd., 2020; Medina, 2019). Son ürünü etanol olan fermantasyonda, pürivat molekülü iki aşamalı olarak gerçekleşen glikoliz reaksiyonu ile etanol ve $\mathrm{CO}_{2}$ 'e dönüşmektedir. İlk aşamada, pürivat molekülünden iki karbonlu asetaldehit ve $\mathrm{CO}_{2}$ oluşurken, ikinci aşamada ise oluşan asetaldehit, $\mathrm{NADH}$ yardımılla etanole indirgenmektedir (Medina, 2019).

Son ürünü laktik asit olan fermantasyonun ise, homolaktik ve heterolaktik olmak üzere iki şekilde gerçekleşebildiği ifade edilmektedir. Homolaktik fermantasyonda; NADH yardımıla pürivat molekülü, Embden-Meyerhoff-Parnas yolu ile, laktat molekülüne dönüşmektedir. Heterolaktik fermantasyonda ise; glikoliz ile oluşan $2 \mathrm{~mol}$ pürivat molekülünden 1 molü, homolaktik fermantasyona benzer olarak laktata indirgenirken, diğer 1 molünün ise; fosfoketolaz yolu ile etanol ve $\mathrm{CO}_{2}$ molekülüne dönüştüğü bilinmektedir (Asunis vd., 2019).

Endüstride farklı fermantasyon teknikleri kullanılabilmektedir. "Backslopping" olarak ifade edilen besleme tekniğinde, daha önce gerçekleştirilen bir fermantasyondaki ürünün bir kısmı, yeni başlatılacak olan fermantasyonda kullanılarak süreç başlatılmaktadır (Kim vd., 2018). Bu şekilde başlatılan bir fermantasyonda, eklenen kültürün miktarı her süreç için sabit olmadığ için, fermantasyonun kontrollü olarak gerçekleşmediği ifade edilmektedir (Vinicius De Melo Pereira vd., 2019). Endüstride kullanilan diğer bir fermantasyon tekniği ise; hammaddeye starter kültür eklenerek fermantasyonun başlatılmasıdır. Starter kültür, kontrollü ve güvenilir bir proses sağlamak amacıyla, fermente edilmek istenen gidaya katılan, tüm özellikleri çeşitli tanımlama yöntemleri ile belirlenmiş olan mikroorganizma kültürüdür (Demirgül ve Sağdıç., 2017). Starter kültürün kullanıldığ1 proseslerde, diğer yöntemlere göre daha hızlı ve ürün yönünden standart bir fermantasyon prosesi sağlanırken, duyusal yönden de, istenilen özelliklere sahip ürünler edilebilmektedir (Vinicius De Melo Pereira vd., 2019).

Starter kültür olarak tanımlanan mikroorganizma gruplar1; hedeflenen son ürüne göre değisskenlik göstermekte olup, çeşitlilik yönünden de oldukça zengindir. Baz1 küf (Penicillium, Rhiropus, Aspergillus), maya (Zygosaccharomyces, Saccharomyces, Candida) ve bakteri cinslerine ait türler (Acetobacter, Brevibacterium, laktik asit bakterileri-LAB) siklıkla starter olarak kullanilan mikroorganizmalar arasındalardır (Dimidi vd., 2019; Tamang vd., 2016).

Endüstriyel açıdan starter kültürler sıv1, toz (püskürtmeli kurutucuda kurutulmuş veya dondurarak kurutulmuş) veya donmuş formda üretilmektedirler. Sıv1 formdaki starter kültürler, kullanımı kolay ve maliyeti düşük olarak belirtilmekle birlikte, kısa süreli raf ömrüne sahip olmaları nedeniyle, kültür aktiviteleri de sinırlı 
olarak karakterize edilmektedirler. Sıv1 formdaki kültürlerin, faj enfeksiyonuna ve kültür kontaminasyonuna açık olmaları nedeniyle de, endüstride daha çok; toz formda ve donmuş formda olan kültürlerin kullanıldıkları ifade edilmektedir (Oğuz ve Andiç, 2019). Sıvı azot içerisinde saklanan donmuş formdaki kültürlerde, genetik stabilitenin uzun süre sağlandığ1 ve depolanma süresinin oldukça uzun olduğu rapor edilmiştir. Hücre kültüründeki su aktivitesinin düşürülmesi esasına dayanan kuru formdaki toz kültürlerin ise, hem işletme maliyetinin düşük olması hem de depolanabilme süresinin uzun olması açısından endüstride daha çok tercih edildikleri bildirilmiştir (Tan vd., 2018).

\section{FERMENTE GIDALARIN \\ FONKSIYYONEL ÖZELLİKLERİ}

Dünya üzerinde sılıkla tüketilen fermente gıdaların insan sağlığı üzerindeki olumlu etkileri, fonksiyonel özellikleri ile açıklanmaktadır (Aslam vd., 2020). Fermente gidalar, probiyotik ve prebiyotik özellikler taşımaktadırlar. Probiyotik özellik; fermente ürünlerin yapılarında bulunan, insanda özellikle bağırsak florasının gelişimine yarar sağlayan canlı mikroorganizmalardan kaynaklanmaktadır (Koçak vd., 2016). Probiyotik fermente bir üründeki canlı mikroorganizma sayisinin fermantasyon sonunda en az; $10^{6}-10^{7}$ $\mathrm{kob} / \mathrm{g}-\mathrm{mL}$ düzeylerinde olması gerektiği bildirilmiştir. Ayrıca probiyotik ürünlerin sağlık üzerindeki olumlu etkilerinin görülebilmesi için günlük alınması gereken dozun $10^{8}-10^{9} \mathrm{kob} / \mathrm{g}$-mL olduğu da ifade edilmektedir (Min vd., 2019). Bir mikroorganizmanın probiyotik olarak değerlendirilebilmesi için belirli özelliklere sahip olması gerektiği belirtilmiştir (Markowiak ve Śliżewska, 2017; Zhao vd., 2019). Probiyotik mikroorganizmalar tüketildiğinde herhangi bir yan etki oluşturmadan, tüketen canlı tarafindan metabolize edilmeli, ayrica patojenik ve toksin oluşturan bir suş olmamalıdır. Probiyotik mikroorganizmaların diğer özellikleri arasında ise; midedeki düşük $\mathrm{pH}$ değeri, sindirime yardımc1 olan safra tuzları ve antibiyotik gibi bazı diş etkenlerden etkilenmeden, canlı olarak bağırsakta kalabilmeleri sayılmaktadır. Laktobasiller ve Bifidobakteriler, yaygin olarak kullanılan probiyotik mikroorganizma cinsleri arasındadırlar.
Laktobasil türlerinin, fermantasyon sirasinda farklı karbon kaynaklarını kullanarak laktik asit oluşturdukları ve asidik ortamlarda da gelişebildikleri bilinmektedir (Holban ve Grumezescu, 2018). Bifidobakteri türlerinin ise; doğal olarak bağırsak mikrobiyotasında bulunarak mikrobiyota dengesinin kurulmasina yardimc1 olarak, allerjik gastrointestial reaksiyonların gelişmesine engel oldukları ifade edilmektedir (Wong vd., 2019). Ayrica, baz1 Pediococcus, Streptococcus, Enterococcus ve Saccharomyces cinslerine ait türlerin de, probiyotik özellik taşıyabildikleri ifade edilmektedir. (Deka vd., 2020). Probiyotiklerin organik asit, etanol, hidrojen peroksit ve bakteriyosinler gibi ürettikleri çeşitli metabolitler ve bu metabolitlerin hücre üzerine yaptıkları çeşitli etkiler ile, patojen mikroorganizmaları inhibe edebilme yeteneğine sahip olduklar1 ifade edilmektedir (Holban ve Grumezcu, 2018). Yapılan bir çalışmada, Lactobacillus'un probiyotik karakterli farklı suşlarının, Salmonella spp.'nin tutunma bölgelerini inhibe ederek kolonizasyonlarını azaltıp enfeksiyonları önleyebileceği belirtilmiştir (Potočnjak vd., 2017). Probiyotik mikroorganizmaların patojenlere olan etkilerinin araştırıldığ1 bir diğer çalışmada ise, 5 farklı probiyotik LAB suşunun (Lactococcus lactis C660, L. lactis ATCC 11454, Lactobacillus casei, Lactobacillus paracasei, Lactobacillus rbamnosus) 7 farklı patojene (E. coli K92, Bacillus cereus, Listeria innocua, Pseudomonas fluorescens, Pseudomonas putida, Staphyloccus aureus ve Staphylococcus epidermidis) karşı inhibisyon etkileri araştırılmıstır. Yapılan araştırma sonucunda; çalışılan LAB suşlarının $E$. coli K92, B. cereus ve L. innocua'nın petri üzerindeki kolonizasyonlarını engelledikleri rapor edilmiştir (Gutiérrez vd., 2016).

Prebiyotik, sindirilmeyen ve lif içeriği yüksek besin elementlerine verilen isim olup bunlar; insan ve hayvan sağlığını olumlu yönde etkileyerek bağırsaktaki kolon bakterilerinin gelişmesini teşvik eden karbonhidratlardır. İnsan bağırsağında bulunan sadece belirli mikroorganizma grupları tarafindan hidroliz edilebilen prebiyotiklerden g1da içeriklerinde en yaygın olanı, oligosakkaritler olarak rapor edilmektedir. Oligosakkaritler, ince bağırsakta metabolize edilmeden kalırlarken, 
kolon bölgesinde özellikle Lactobacillus ve Bifidobacterium türlerinin gelişmiş enzim sistemleri ile fermente edilebilmektedirler (Holscher, 2017). Doğal prebiyotik türlerin dışında, karbonhidratların çeşitli enzimlerle hidrolizi ile oluşturulan sentetik prebiyotikler de belirtilmiştir. Sentetik prebiyotiklere örnek olarak ise inülin, laktosükroz ve laktüloz verilebilir (Holban ve Grumezcu., 2018).

Bazı fermente ürünlerin içeriğindeki $\mathrm{LAB}$ bu ürünlerin "probiyotik" olarak adlandırılmasında önem teşkil ederler. LAB, karbonhidrat fermantasyonu süresince ana ürün olarak laktik asit üreten ve biyoteknolojik açıdan gıda endüstrisinde oldukça önemli; Gram pozitif bakteri cinslerinden oluşan bir grup olarak tanımlanmaktadır (Alvarez-Sieiro vd., 2016). LAB taksonomisindeki başlıca cinsler; Lactobacillus, Pediococcus, Aerococcus, Carnobacterium, Enterococcus, Tetragenococcus, Vagococcus, Lenconostoc, Oenococcus, Weissella, Streptococcus ve Lactococcus'tur (Iskandar vd., 2019). Baz1 LAB'nin fermantasyon süresince, laktik asit dışında, bakteriyosin adı verilen antimikrobiyel maddeler de üretebildikleri bilinmektedir. Bakteriyosinler, farklı mikroorganizma gruplarına karşı inhibitör etki gösteren, antibiyotiklerle karşılaştırıldığında daha dar bir etki spektrumuna sahip, gida koruyucu olarak da kullanılabilen ve ribozomda sentezlenen protein yapısındaki bileşiklerdir (Chikindas vd., 2018; Yalçın ve Üstündağ, 2017). Bu antimikrobiyel proteinlerin, gidaların fizikokimyasal yapısını bozmadan ve insan sağlı̆ı üzerinde herhangi olumsuz bir etki yaratmadan çeşitli mikroorganizmaları inhibe edebildikleri belirtilmiştir. Bakteriyosinlerin etki mekanizmaları bakteriyosin çeşidine göre değişmekle birlikte genel olarak; etki edeceği bakterinin hücre duvarının bütünlügünün bozulmasına sebebiyet verme ve hücredeki protein ile nükleik asit sentezini engelleyerek hücreyi inhibe etmek olarak belirtilmektedir (Ahmad vd., 2017).

LAB, besinlerde küf gelişimini kontrol altına almak ve engellemek için kullanılan; fiziksel ve kimyasal yöntemlere alternatif olarak kullanilabilmektedirler. LAB'nin antifungal aktivitesi, fermantasyon süresince üretilen başta organik asitler ve başka diğer metabolitlerin küflerdeki flament ve spor gelişimini engellemesi ile açıklanmaktadır (Kıvanç ve Kovanc1, 2017). Bu konuda yapılan bir çalışmada, Lactobacillus plantarum'un 88 adet suşunun, yulaf bazlı ürünler üzerinde gelişebilen Aspergillus niger, Aspergillus flavus, Penicillium expansum gibi çeşitli küf türlerine karşı antifungal aktivitelerinin araştırıldığ1 bildirilmiştir. Bu çalışmada, MRS agar üzerine spotlanan L. plantarum suşları üzerine her küf türünden Malt Extract broth'da geliştirilen yaklaşık $1 \times 10^{6}$ spor/mL yoğunluğunda kültür aşılanmış, 5 günlük inkübasyonun ardından oluşan inhibisyon zonlarının büyüklüklerinin incelendiği ifade edilmiştir. Sonuç olarak; $L$. plantarum suşların gelişme evresinde ürettiği laktik asitin bir türevi olan fenillaktik asidin küflerin gelişimini belirli ölçülerde engellediği rapor edilmiştir (Russo vd., 2017).

LAB'nin, fermantasyon süresince çeşitli tekrarlayan şeker üniteleri içeren bazı ekzopolisakkaritler de (EPS) sentezleyebildikleri bilinmektedir (Caggianiello vd., 2016). Bu ekzopolisakkaritlerin, bakteriye çevresel stres faktörlerine karşı kendini savunma ve biyofilm oluşturma yeteneklerini kazandırırken, insan sağlığ1 üzerinde de bağışıklığ1 güçlendirici ve kolestrol düşürücü etkileri olduğu ifade edilmektedir (Alp ve Kuleaşan, 2019; Caggianiello vd., 2016). Ayrica, LAB tarafindan üretilen ekzopolisakkaritlerin, prebiyotik özellik de gösterdikleri ve bu durumun fermente ürünlerdeki LAB'nin probiyotik özelliklerini destekler nitelikte olduğu da ifade edilmektedir (Zannini vd., 2016). Fermente ürünlerde, LAB tarafindan üretilen ekzopolisakkaritlerin ayrıca; ürünün yapısal özelliklerini de geliştirerek, bir stabilite de sağladığı belirtilmektedir (Leroy ve De Vuyst, 2016).

Fermente ürünlerin içeriğinde, fonksiyonel olarak nitelendirilebilecek; biyoaktif peptit oluşumlarının da gözlemlendiği ifade edilmiştir. Biyoaktif peptitler, gida kaynaklı proteinlerin spesifik şekilde hidrolize olması ile oluşan, sağlı üzerinde olumlu etkileri bulunan, her molekülünde genellikle; 3-20 aminoasit bulunduran yapılardır (Ay ve Şanl1, 2018). Fermente ürünlerde biyoaktif 
peptitlerin oluşumunun iki farklı şekilde gerçekleşebildiği rapor edilmektedir. Biyoaktif peptidlerin, fermantasyon ve olgunlaşma süresince meydana geldiği ve mikroorganizmanın kendi proteolitik sistemi sonucunda ya da endojen proteolitik enzimler yardımıyla oluştukları ifade edilmektedir (Frias vd., 2016). Biyoaktif peptitlerin aktivitesi, yapisinda bulunan aminoasitlerin sayıs1 ve bu aminoasitlerin dizilimi ile doğrudan ilişkilendirilmektedir. Fermantasyon sonrasında ortaya çıkan biyoaktif peptitlerin kan şekerini düşüren hormon; insülinin oluşumunu teşvik ettiği, ayrıca vücudun kan basıncını ve su dengesini de düzenleyerek antihipertansif özellik de gösterdiği belirlenmiştir (Daliri vd., 2017). Antihipertansif etkinin, Özellikle fermente süt ürünlerinde bulunan anjiyotensin inhibitör peptitlerinin (ACE), kan basıncinı dengelemesi ile ortaya çıtığı yapılan çalışmalar ile doğrulanmıştır (Ay ve Şanll., 2018; Şanlier vd., 2019; Tamang vd., 2016). Fermente süt ürünleri ile yapilan bir çalışmada, 22 adet $L$. casei suşunun, kendi aralarında ACE inhibitör peptidi aktivitesi yönünden değerlendirildikleri ve bu suşlar arasından IMAU10408 ve IMAU20411 suşlarının en yüksek ACE inhibitör peptidi aktivitesine sahip olduklarının belirlendiği rapor edilmiştir (Li vd., 2017).

Hipertansif farelerle yapılan farklı bir diğer çalışmada; L. lactis NRRL B-50571 suşunu içeren fermente süt ürünlerindeki ACE inhibitörü peptidi aktivitesinin, kan basınc1 üzerindeki etkileri araştırılmıştır. Söz konusu araştırmada; ACE inhibitörü peptidi aktivitesinin, hipertansif farelerde, 6 hafta süre ile takip edildiği ifade edilmiştir. Bildirilen sonuçlarda, L. lactis NRRL B50571 ile fermente edilmiş sütle beslenen hipertansif farelerde kan basıncının düştüğü ifade edilirken, ayrica peptid aktivitesinin plazmada nitrik oksit oluşumunu artırarak antioksidan etki de gösterdiği rapor edilmiştir (Beltrán-Barrientos vd., 2018).

Biyoaktif peptitlerin ayrıca, çeşitli bakteri, maya ve virüslere karşı da antimikrobiyel özellik göstermelerinin yanısıra, oksidatif stresi önleyici ve serbest radikalleri bağlayıcı etki göstermek suretiyle antioksidan özelliklerinin de bulunduğu belirtilmektedir (Ay ve Şanli., 2018). L. plantarum'un farklı suşları ile yapılan bir çalışmada, süt ürünlerinin fermantasyonu sonucunda oluşan peptit fraksiyonlarının antioksidan aktivitesinin 2,2'-Azino-bis-3-ethylbenzothiazoline-6-sulfonic acid (ABTS) metodu ile incelendiği suşlar arasında L. plantarum 55 suşunun antioksidan aktivitesinin oldukça yüksek bulunduğu rapor edilmiştir (Aguilar-Toalá vd., 2017).

\section{FERMENTE ÜRÜNLERİN SAĞLIK ÜZERİNDEKİ ETKILERİ}

Fermantasyon sonucunda ürün olarak çeşitli organik asitler, etanol ve antimikrobiyeller (bakteriyosinler ve antifungal maddeler) oluştuğu için fermantasyon, biyolojik bir muhafaza yöntemi olarak değerlendirilmektedir (Marco vd., 2017). Ayrica, fermantasyon sonucunda son ürünün hammaddeden farklı olarak, hem fiziksel (kıvam, doku vb.) hem de duyusal açıdan (tat, koku vb.) istenen özellikler kazandığ1 da bilinmektedir (Mokoena vd., 2016). Bu özellikleri dışında fermente ürünlerde, insan sağllğıını olumlu yönde etkileyen bazı fonksiyonel bileşenlerin bulunduğu da, güncel çalışmalar ile tespit edilmiştir. Dünya üzerinde sağlıklı yaşamı destekleyen, fonksiyonel bileşenler içeren gıdaların tüketiminin de giderek yaygınlaştığı ifade edilmektedir. Fermente gıdaların, başta bağırsak mikrobiyotası olmak üzere, vücudun farklı bölgeleri üzerinde olumlu etkiler göstererek, sağlıklı bir yaşamı desteklediği ve çeşitli hastalıklara karşı vücudu koruyabildiği de belirtilmektedir (Dimidi vd., 2019).

İnsan bağırsağında bakteri, maya gibi mikroorganizma gruplarından oluşan özel bir mikroflora bulunduğu ve "mikrobiyota" olarak adlandırıldığı bilinmektedir (Özdemir ve Demirel, 2017). İnsan bağırsak mikrobiyotasında, yoğun olarak Firmicutes ve Bacteroidetes familyasina ait cinsler bulunmakla birlikte, Actinobacteria, Proteobacteria familyasina ait cinslerin de doğal mikrofloraya dahil oldukları ifade edilmektedir (Foster vd., 2017; Thursby ve Juge, 2017). Bu gruplar dişında bağırsak mikrobiyotasındaki mikroflora yoğunluğu ve içeriğinin, kişinin beslenme biçimi, bulunulan coğrafya, antibiyotik kullanımı, anne sütü alımı gibi etkilerle bireyden 
bireye değişkenlik gösterebileceği de bildirilmektedir (Özdemir ve Demirel, 2017). Bağırsak mikrobiyotasının, bağırsağa gelene kadar sindirime uğramayan besinleri y1kıma uğratarak, sindirimin kolaylaşmasına yardımcı olduğu belirtilmektedir. Yıkım işlemleri sonucunda meydana gelen çeşitli metabolitlerin bağışıklık sistemi ile metabolizma dengesinin gelişiminde önemli rol oynadığ1 da rapor edilmektedir (Thursby ve Juge, 2017). Bağırsak mikrobiyotasi; bağırsak duvarında yaklaşık 100 milyon sinir hücresinden oluşan karmaşık yapılı enterik sinir sistemi içermekte olup, bu enterik sinir sistemi bazen "ikinci beyin" olarak da adlandırlmaktadır (Doğan vd., 2018). Son y1llarda nörogastroenteroloji alanında yapilan çalışmalarda, bağırsak mikrobiyotası ile merkezi sinir sistemi arasında "bağırsak-beyin ekseni" olarak da adlandırılan bir ilişki olduğu ortaya konulmuştur (Dinan ve Cryan, 2017). Bağırsakbeyin ekseninin, vücutta nöral, hormonal ve immünolojik düzeylere göre düzenlendiği ifade edilmektedir (Çetinbaş vd., 2017). Bu bağlamda bağırsak-beyin ekseninde herhangi bir anormali olması durumunda, hem gastrointestinal hem de merkezi sinir sistemi ile ilgili rahatsızliklar görülebileceği rapor edilmiştir (Ghaisas vd., 2016; Mota de Carvalho vd., 2018).

Sağlıklı bir insanın bağırsak mikrobiyotasındaki doğal mikrobiyel floranın korunabilmesi, gastrointestinal rahatsılıkların ve gastrointestinal rahatsızlıklara bağlı başka hastalıkların önüne geçebilmenin önemli koşullarından biri olarak ifade edilmektedir. Probiyotik içerikli fermente ürünlerin tüketimi, sağlıklı bağırsak mikrobiyotası ile doğrudan ilişkilendirilmiş olup, bu ürünlerin bağışıklık sistemini güçlendiren etkilerinin olduğu da, çalışmalar ile ortaya konulmuştur (Aslam vd., 2020). Dünya çapında oldukça yaygın olan obezite hastalığının, bağırsak mikrobiyotası ile doğrudan ilişskili olduğu belirtilmektedir. Obezite hastalığ1 vücuda alınan kalori ve vücutta tüketilen kalori arasindaki dengesizlik sonucunda, vücutta fazla yağ dokusu birikmesi olarak ifade edilmektedir (Boulangé vd., 2016). Yağ oran1 yüksek diyet ile ilişskilendirilen obezite durumunda, bağırsak mikrobiyotasında doğal olarak bulunması gereken mikroorganizma dengesinin bozularak, epitel dokudaki bütünlüğun zarar gördüğü belirtilmektedir (Bagarolli vd., 2017). Epitel dokunun zarar görmesi durumunda ise; kişinin kendi doku hücrelerine karşı oluşan kronik inflamasyon sonucunda, dokularda kansere varan sonuçlar ile karşılaşılabileceği rapor edilmiştir (Durmuş vd., 2018). Obezite göstergesi olarak, insanlarda doğal bağırsak florasında bulunan Firmicutes ile Bacteroidetes üyesi cinslerinin birbirlerine oranının (F/B oranı), bir biyomarker olarak kabul edildiği ifade edilmektedir (Tseng ve Wu, 2019). Obezite ile ilişkilendirilen ve kan şekerinin daimi yüksekliğine neden olan metabolik rahatsızlık; diyabet hastalı̆̆ının da, bağırsak mikrobiyotasındaki flora ile doğrudan ilişkili olduğu ifade edilmektedir. Diyabet dışında, vücutta salgilanan insülinin yağ, kas ve karaciğer hücrelerinde yeterli tepkiyi oluşturamaması durumunda oluşan insülin direnci de; obezite ile ilişkilendirilmektedir (Durmuş vd., 2018).

Kompleks diyet lifleri olan prebiyotiklerin, insan bağırsak mikroflorası tarafindan fermantasyona uğratılması sonucunda oluşan metabolitlerden birisi olan; kısa zincirli bir yağ asidi; bütirat molekülünün, insülin hassasiyetini ve enerji metabolizmasını etkilediği ifade edilmektedir. Fermantasyon sonucu oluşan bütirat molekülü ile, karaciğerdeki kolesterolden sentezlenerek bağırsağa salınan safra asidi, vücuttaki şeker metabolizmas1 ile ilgili GIP, NPY, GLP-1 ve GLP-2 gibi birkaç hormonun seviyesini etkileyerek, insülin salgilanmasını uyardığı ve kandaki glukoz seviyesini düşürdüğü rapor edilmektedir (Fatih, 2017).

Gastrointestinal rahatsızlıklardan bir diğeri ise; kronik enflamasyonlar olarak bildirilmektedir. Bu enflamasyonlardan birine neden olan; Helicobacter pylori mide mukozasına yerleşebilen, Gram negatif bir bakteri olup, kronik gastrit, ülser hastaliğ1, kronik gastrit, mide kanseri ve duodenal ülser hastalı̆g gibi çeşitli gastrointestinal problemlerde önemli rolü olan bir patojendir (Akdeniz vd., 2018). H. pylorinin, amonyak üreten üreaz enzimini bulundurmasi nedeniyle, asidik mide ortamını nötralize edebildiği ve asidik ortama karş1 dirençli olma özelliği ile de, mide epiteline tutunmasının kolay olduğu belirtilmiştir (Akdeniz 
vd., 2018). H. pylori tedavisinde; antibiyotikler sıkça kullanılsa da, patojenin zamanla bu antibiyotiklere karşı direnç göstermesi ve görülen yan etkiler nedeniyle farklı tedavi yöntemlerinin denendiği rapor edilmektedir. Bu alternatiflerden birisi de; probiyotik tedavisi olarak açıklanmaktadır. Birçok çalışmada probiyotiklerin ürettikleri bakteriyosinlerin, $\mathrm{H}_{2} \mathrm{O}_{2}$ ve kısa zincirli yağ asitleri sayesinde, $H$. pylori inhibisyonunu sağlanabildiğine dair kanıtların elde edildiği bildirilmektedir (Akdeniz vd., 2018; Vítor ve Vale, 2011). Ayrıca probiyotiklerin ürettikleri laktik asitin sağladığ 1 asidik ortam, üreaz enzimini de inhibe edebildiğinden, mide ortamının doğal florasının korunmasına yardımcı olarak $H$. pylori eradikasyonunu sağladığı rapor edilmiştir (Kim vd., 2014).

Tüm vücut dokuları için temel yapıtaşı olarak kabul edilen kolesterolün kandaki seviyesinin normalin üzerinde seyretmesinin, kalp damar hastalıklarının görülme riskini artıran faktörlerden biri olarak değerlendirildiği bilinmektedir. Probiyotik bakterilerin kandaki kolesterolü düşürücü etkilerinin olduğu da ifade edilmektedir. Probiyotik bakterilerin, sindirim esnasinda ince bağırsakta safra tuzlarını serbest forma geçirerek safra tuzlarının çözünürlügünü azalttıkları belirtilmiştir. $\mathrm{Bu}$ durumda bağırsak kanalından normale göre daha fazla safra asidi atıldığından karaciğere dönen safra asidi miktarının da azaldığ belirtilmektedir. Karaciğerin bu durumda; kandaki kolesterolü kullanarak daha fazla safra asidi sentezlediği ve kandaki kolesterol seviyesinin düşürdüğ̈̈ belirlenmiştir (Alp ve Ertürkmen, 2017).

Yapılan araştırmalarda, bağırsak-beyin ekseni ilişkisinden ötürü, kronik bağırsak rahatsızlıklarının, nörodejeneretif ve psikolojik rahatsızlıklara da neden olabileceği belirlenmiştir (Serra vd., 2019). Bağırsak mikrobiyotasının ilaç kullanımı, diyet, fizyolojik adaptasyon gibi çeşitli dış etmenlerle değişime uğrayarak kendi içindeki dengesinin bozulmasi; disbiyosis olarak ifade edilmektedir (Sugeçti vd., 2019). Disbiyosis durumunda oluşan bilişsel davranış bozuklukları sonucunda; nörodejeneratif rahatsizlikların görüldüğü bildirilmektedir. Bağırsak mikrobiyotasının doğasının korunması ile bu rahatsızlıkların gelissim sürecinin değiştirilebileceğine dair çalışmalar yapılmaktadır. $\mathrm{Bu}$ çalışmalardan birinde; Alzeimer ve Parkinson'un ilerleme sürecinin besinsel takviyeler ile değiştirilebileceği vurgulanmıştır (Lee ve Pan, 2017; Tseng vd., 2016). Bir diğer araştırmada ise; fermente pirinç özütünün içeriğinde bulunan farklı antioksidatif ve antiinflamatuar özellikteki metabolitlerin, Parkinson tedavisi için önemli bir potansiyel olduklar1 rapor edilmiştir (Tseng vd., 2016). Zihinsel gelişimde eksiklik nedeniyle meydana gelen kavrama bozukluğu ile çevre ile etkileşimde sorun yaşanmasına neden olan; otizm spektrum bozukluğu tespit edilen bireylerin otistik davranışları ile bağırsak beyin ekseni arasında da ilişki olduğu ifade edilmektedir ( $\mathrm{Li}$ ve Zhou, 2016). Bu konuda yapılan bir çalışmada; otizm spektrum bozukluğu tespit edilen, 2 ile 4 yaş arasındaki çocukların bağırsak mikrobiyotasının, bu yaşta bulunan sağlıklı çocuklarınkine göre farkll1ık gösterdiği tespit edilmiştir. Buna göre hasta bireylerde, sağlıklı insanlara göre; Bacteroidetes ve Proteobacteria gruplarının artış gösterdikleri, Actinobacteria grubunun ise azaldığ1 ifade edilmiştir. Ayrıca bu çalışmada, bu yaş aralı̆̆ındaki çocukların bağırsak florasında dominant olarak bulunması gereken Bifidobacterium longum türü saptanmazken, hasta çocukların bağırsak mikrobiyotasında, önemli bir bütirat üreticisi olan; Faecalibacterium prausnitrii türünün yüksek seviyelerde bulunduğu ifade edilmiştir (Coretti vd., 2018).

Bağırsak-beyin ekseni ilişkisini farklı şekilde ifade eden "psikobiyota"nın fermente gidalar ile doğrudan ilişkilendirildiği belirtilmiştir (Aslam vd., 2020) . Yapılan birçok çalışmada, fermente gidalarda bulunan baz1 probiyotik mikroorganizmaların yeterli miktarda tüketildiklerinde, ürettikleri çeşitli metabolitler sayesinde psikolojik rahatsızlıklar üzerinde olumlu etkiler gösterdiği tespit edilmiştir. Probiyotik bu mikroorganizmalara "psikobiyotik" ad1 verilmektedir (Zhou ve Foster, 2015). Psikobiyotiklerin, serotonin öncüsü triptofan ve dopamin öncüsü tirozin ve $\gamma$-amino bütirik asit gibi nörotransmitter maddeleri üreterek, duygu 
durumu üzerinde olumlu etkiler yarattığ1 ve anksiyete semptomlarını azalttığ1 rapor edilmektedir (Bermúdez-Humarán vd., 2019). Psikobiyotik bir mikroorganizma olan $L$. plantarum PS128 suşu ile yapilan bir çalışmada, 16 gün boyunca farelere uygulanan probiyotik takviyesi sonucunda, farelerdeki stres seviyelerinin ve depresyon davranışlarının önemli ölçüde azaldığı ifade edilmiştir (Liu vd., 2016). Bu konuda insan üzerinde yapılan klinik çalışmalar halen devam etmekle birlikte, psikobiyotik mikroorganizmaların tüketimi ile değişen bağırsak mikrobiyotası sayesinde, psikolojik rahatsızlıkların semptomlarının ilaç kullanmadan azaltılabileceği belirlenmiş ve probiyotik mikroorganizmalar içeren fonksiyonel özellikteki fermente gıdaların tedavi amaçlı tüketilmeleri konusu oldukça önem kazanmıştır (Misra ve Monhanty, 2019).

\section{SONUÇ}

Günümüzde, hızla büyüyen dünya nüfusu içerisinde, insanların sağlıklı beslenme konusunda giderek daha fazla bilinçlenmeye başladıkları ifade edilmektedir. Bunun sonucu olarak da insanlarnn, sağlıklı beslenme alışkanlıkları edinmeye ve fonksiyonel özellikteki gidaları daha fazla tüketmeye başladıkları belirtilmektedir. Eskiden sadece gidaların daha uzun süre muhafaza edilmesi ve son üründe karakteristik tat/koku özelliklerinin geliştirilmesi için kullanılan fermentasyon tekniğinin, günümüzde; fermente gıdaların fonksiyonel özelliklerinin anlaşılmasıly, daha farklı amaçlarla kullanılan bir yöntem haline geldiği belirtilmektedir. İnsan sağlı̆̆ üzerinde, hem gastrointestinal hem de nörolojik açıdan birçok yararlı etki gösteren ve tansiyon, şeker gibi çeşitli kronik rahatsızlıkların etkilerini azaltmaya yardımc1 olan fermente gidaların, bilim dünyasında yoğun olarak çalışlan konular arasına girdiği bildirilmektedir. Bunun yanısıra; her fermente ürün grubunun, sağlık üzerindeki olumlu etkilerinin ayrı ayrı incelenmeye değer ve faydalı olacağı da düşünülmektedir.

\section{ÇIKAR ÇATIŞMASI}

$\mathrm{Bu}$ makale ile ilgili olarak başka kişiler ve/veya kurumlar arasında bir çıkar çatışması yoktur.

\section{YAZAR KATKILARI}

Tüm yazarlar makalenin yapilmasinda, yazılmasında ve yayınlanmasında eşit katkı sağlamışlardır. Makalenin hazırlanmasında başka kişi ve/veya kurumların katkısı yoktur.

\section{KAYNAKLAR}

Aguilar-Toalá, J., Santiago-López, L., Peres, C., Peres, C., Garcia, H., Vallejo-Cordoba, B., González-Córdova, A., Hernández-Mendoza, A. (2017). Assessment of multifunctional activity of bioactive peptides derived from fermented milk by specific Lactobacillus plantarum strains. J Dairy Sci, 100(1):65-75. doi:10.3168/jds.2016-11846

Ahmad, V., Khan, M. S., Jamal, Q. M. S., Alzohairy, M. A., Al Karaawi, M. A., Siddiqui, M. U. (2017). Antimicrobial potential of bacteriocins: in therapy, agriculture and food preservation. Int $J$ Antimicrob Agents, 49(1): 1-11. doi:10.1016/j.ijantimicag.2016.08.016

Akdeniz, V., Akalın, A. S., Özer, E. (2018). Helicobacter pylori enfeksiyonunda probiyotiklerin rolü. Gıda, 43(6): 943-956. doi:10.15237/gida.GD18062

Alp, D., Ertürkmen, P. (2017). Probiyotik olarak kullanılan Lactobacillus spp. suşlarının kolesterol düşürücü etkileri ve olası mekanizmalar. $M A K U ̈$ Sag Bil Enst Derg, 8(1):108-113.

Alp, D., Kuleaşan, H. (2019). Farklı kaynaklardan izole edilmiş laktik asit bakterilerinin ekzopolisakkarit üretimi ve kolesterol asimilasyon yeteneklerinin belirlenmesi. Grda, 44(2): 191-201. doi:10.15237/gida.GD18059

Alvarez-Sieiro, P., Montalbán-López, M., Mu, D., Kuipers, O. P. (2016). Bacteriocins of lactic acid bacteria: extending the family. Appl Microbiol Biotechnol, 100(7): 2939-2951. doi:10.1007/s00253-016-7343-9

Asghar, F., Ali, S., Goraya, A., Javaid, I., Hussain, Z. (2017). A Review on the Role of Fermented Foods as Health Promoters. Int J Sci Eng Technol, 3: 141-148. doi:10.32628/IJSRST173415

Aslam, H., Green, J., Jacka, F. N., Collier, F., Berk, M., Pasco, J., Dawson, S. L. (2020). Fermented foods, the gut and mental health: A mechanistic overview with implications for 
depression and anxiety. Nutr Neurosci, 1-13. doi:10.1080/1028415X.2018

Asunis, F., De Gioannis, G., Isipato, M., Muntoni, A., Polettini, A., Pomi, R., Rossi, A., Spiga, D. (2019). Control of fermentation duration and $\mathrm{pH}$ to orient biochemicals and biofuels production from cheese whey. Bioresour Technol, 289: 121722. doi:10.1016/j.biortech.2019.121722

Ay, C., Şanl1, T. (2018). Süt Ürünlerinde Biyoaktif Peptitlerin Olușumu ve Fonksiyonel Özellikleri. ADÜ Ziraat Derg, 15(1): 115-120. doi:10.25308/aduziraat.340581

Bagarolli, R. A., Tobar, N., Oliveira, A. G., Araújo, T. G., Carvalho, B. M., Rocha, G. Z., Vecina, J. F., Calisto, K., Guadagnini, D., Prada, P. O. (2017). Probiotics modulate gut microbiota and improve insulin sensitivity in DIO mice. $J$ Nutr Biochem, 50: 16-25. doi:10.1016/j.jnutbio.2017.08.006

Beltrán-Barrientos, L. M., Hernández-Mendoza, A., González-Córdova, A. F., Astiazarán-García, H., Esparza-Romero, J., Vallejo-Córdoba, B. (2018). Mechanistic pathways underlying the antihypertensive effect of fermented milk with Lactococcus lactis NRRL B-50571 in spontaneously hypertensive rats. Nutrients, 10(3): 262. doi:10.3390/nu10030262

Bermúdez-Humarán, L. G., Salinas, E., Ortiz, G. G., Ramirez-Jirano, L. J., Morales, J. A., BitzerQuintero, O. K. (2019). From probiotics to psychobiotics: live beneficial bacteria which act on the Brain-Gut axis. Nutrients, 11(4),:890-912. doi:10.3390/nu11040890

Boulangé, C. L., Neves, A. L., Chilloux, J., Nicholson, J. K., Dumas, M. E. (2016). Impact of the gut microbiota on inflammation, obesity, and metabolic disease. Genome Med, 8(1): 1-12. doi:10.1186/s13073-016-0303-2.

Caggianiello, G., Kleerebezem, M., Spano, G. (2016). Exopolysaccharides produced by lactic acid bacteria: from health-promoting benefits to stress tolerance mechanisms. Appl Microbiol Biotechnol, 100(9): 3877-3886. doi:10.1007/s00253-016-7471-2
Çetinbaş, S., Kemeriz, F., Göker, G., Biçer, İ., Velioğlu, Y. S. (2017). İnsan Mikrobiyomu: Beslenme ve Sağllk Üzerindeki Etkileri. Akademik Gida, 15(4): 409-415. doi:10.24323/akademikgida.370267

Chikindas, M. L., Weeks, R., Drider, D., Chistyakov, V. A., Dicks, L. M. (2018). Functions and emerging applications of bacteriocins. Curr Opin Biotechnol, 49: 23-28. doi:10.1016/j.copbio.2017.07.011

Coretti, L., Paparo, L., Riccio, M., Amato, F., Cuomo, M., Natale, A., Borrelli, L., Corrado, G., Comegna, M., Buommino, E. (2018). Gut microbiota features in young children with autism spectrum disorders. Front Microbiol, 9: 3146. doi:10.3389/fmicb.2018.03146

Daliri, E., Oh, D., Lee, B. (2017). Bioactive peptides. Foods, 6(5): 32. doi:10.3390/foods6050032.

Deka, S. C., Seth, D., Hulle, N. R. S. (Eds.). (2020). Food Bioactives: Functionality and Applications in Human Health. USA: CRC Press.

Demirgül, F., Sağdıç, O. (2017). Laktik Starter Kültür Üretim Teknolojisi. EJOSAT, 7(11): 2737.

Dimidi, E., Cox, S. R., Rossi, M., Whelan, K. (2019). Fermented Foods: Definitions and characteristics, impact on the gut microbiota and effects on gastrointestinal health and disease. Nutrients, 11(8): 1806. doi:10.3390/nu11081806

Dinan, T. G., Cryan, J. F. (2017). The microbiome-gut-brain axis in health and disease. Gastroentol Clin N, 46(1): 77-89. doi:10.1016/j.gtc.2016.09.007

Doğan, A., Yaşar, S., Kayhan, S., Kırmızıgöz, Ş., Kaplan, A. (2018). Bağırsak-beyin aks1. Türk Nöroşir Derg, 28(3): 377-379. doi:10.5336/jtracom.2018-61683

Durmuş, E., Aypak, C., Görpelioğlu, S. (2018). Tip 2 Diyabet Hastalarında Kronik İnflamasyon Belirteci Olarak Lökosit Sayımı. Ankara Med J, 1(4): 253-259. doi:1017098/amj.364164 
Fatih, K. (2017). Bağırsak Mikrobiyotasının Obezite, İnsülin Direnci ve Diyabetteki Rolü. J Biotechnol and Strategic Health Res, 1: 68-80.

Foster, J. A., Rinaman, L., Cryan, J. F. (2017). Stress the gut-brain axis: regulation by the microbiome. Neurobiol Stress, 7: 124-136. doi:10.1016/j.ynstr.2017.03.001

Frias, J., Martinez-Villaluenga, C., Peñas, E. (2016). Fermented Foods in Health and Disease Prevention. United Kingdom: Elsevier.

Ghaisas, S., Maher, J., Kanthasamy, A. (2016). Gut microbiome in health and disease: Linking the microbiome-gut-brain axis and environmental factors in the pathogenesis of systemic and neurodegenerative diseases. Pharmacol Ther, 158: 52-62. doi:10.1016/j.pharmthera.2015.11.012

Gutiérrez, S., Martínez-Blanco, H., RodríguezAparicio, L., Ferrero, M. (2016). Effect of fermented broth from lactic acid bacteria on pathogenic bacteria proliferation. I Dairy Sci, 99(4): 2654-2665. doi:10.3168/jds.2015-10439

Holban, A. M., Grumezescu, A. M. (Eds.). (2018). Diet, Microbiome and Health (Vol. 11). UK: Elsevier.

Holscher, H. D. (2017). Dietary fiber and prebiotics and the gastrointestinal microbiota. Gut Microbes, $\quad 8(2): \quad 172-184$ doi:10.1080/19490976.2017.1290756

Iskandar, C. F., Cailliez-Grimal, C., Borges, F., Revol-Junelles, A.M. (2019). Review of lactose and galactose metabolism in Lactic Acid Bacteria dedicated to expert genomic annotation. Trends Food Sci Technol. 88: 121-132. doi:10.1016/j.tifs.2019.03.020

Kim, D. H., Jeong, D., Song, K. Y., Seo, K. H. (2018). Comparison of traditional and backslopping methods for kefir fermentation based on physicochemical and microbiological characteristics. LTW - Food Sci Technol, 97: 503507. doi:10.1016/j.lwt.2018.07.023

Kim, J. E., Kim, M. S., Yoon, Y. S., Chung, M. J., Yum, D. Y. (2014). Use of selected lactic acid bacteria in the eradication of Helicobacter pylori infection. $J$ Microbiol, 52(11): 955-962. doi:10.1007/s12275-014-4355-y
Kıvanç, M., Kovanc1, P. (2017). Fermente g1dalardan izole edilen laktik asit bakterilerinin antifungal aktivitesinin belirlenmesi. Gida, 42(5): 477-484. doi:10.15237/gida.GD17012

Koçak, Y., Findık, A., Çiftçi, A. (2016). Probiyotikler: Genel Özellikleri ve Güvenilirlikleri. Etlik Vet Mikrobiyol Derg, 27(2): 118-122.

Lee, C., Pan, T. (2017). The prevention of Alzheimer's disease and Parkinson's disease by Monascus purpureus NTU 568-fermented compounds. I Alzheimers Dis Parkinsonism, 7(342): 2161-0460. doi:10.4172/2161-0460.1000342

Leroy, F., De Vuyst, L. (2016). Advances in production and simplified methods for recovery and quantification of exopolysaccharides for applications in food and health. J Dairy Sci, 99(4): 3229-3238. doi:10.3168/jds.2015-9936

Levent, H., Cavuldak, Ö. A. (2017). Geleneksel Fermente Bir İçecek: Boza. Akademik Gıda, 15(3): 300-307. doi:10.24323/akademik-gida.345273

Li, C., Kwok, L. Y., Mi, Z., Bala, J., Xue, J., Yang, J., Ma, Y., Zhang, H., Chen, Y. (2017). Characterization of the angiotensin-converting enzyme inhibitory activity of fermented milks produced with Lactobacillus casei. I Dairy Sci, 100(12): 9495-9507. doi:10.3168/jds.2017-12970

Li, Q., Zhou, J. M. (2016). The microbiota-gutbrain axis and its potential therapeutic role in autism spectrum disorder. Neuroscience, 324: 131139. doi:10.1016/j.neuroscience.2016.03.013

Liu, Y. W., Liu, W. H., Wu, C. C., Juan, Y. C., Wu, Y. C., Tsai, H. P., Wang, S., Tsai, Y. C. (2016). Psychotropic effects of Lactobacillus plantarum PS128 in early life-stressed and naïve adult mice. Brain Res, 1631: 1-12. doi:10.1016/j.brainres.2015.11.018

Marco, M. L., Heeney, D., Binda, S., Cifelli, C. J., Cotter, P. D., Foligné, B., Gänzle, M., Kort, R., Pasin, G., Pihlanto, A. (2017). Health benefits of fermented foods: microbiota and beyond. Curr Opin Biotechnol, 44: 94-102. doi:10.1016/j.copbio.2016.11.010

Markowiak, P., Śliżewska, K. (2017). Effects of probiotics, prebiotics, and synbiotics on human 
health. $\quad$ Nutrients, $\quad 9(9)$ : 1021. doi:10.3390/nu9091021

Medina, R. (2019). Fermentation Technology. United Kingdom: ED-TECH Press.

Min, M., Bunt, C. R., Mason, S. L., Hussain, M. A. (2019). Non-dairy probiotic food products: An emerging group of functional foods. Crit Rev Food Sci Nutr, 59(16): 2626-2641. doi: 10.1080/10408398.2018.1462760

Misra, S., Monhanty, D. (2019) Psychobiotics: A new approach for treating mental illnesses?. Crit Rev Food Sci Nutr, 59(8): 1230-1236. doi: 10.1080/10408398.2017.1399860.

Mokoena, M. P., Mutanda, T., Olaniran, A. O. (2016). Perspectives on the probiotic potential of lactic acid bacteria from African traditional fermented foods and beverages. Food Nutr Res, 60(1): 29630. doi:10.3402/fnr.v60.29630

Mota de Carvalho, N., Costa, E., Silva, S., Pimentel, L., Fernandes, T., Pintado, M. (2018). Fermented foods and beverages in human diet and their influence on gut microbiota and health. Fermentation, 4(4): 90. doi:10.3390/fermentation4040090

Oğuz, Ş., Andiç, S. (2019). Peynir üretiminde kullanilan starter kültürler. Gıda, 44(6): 1174-1196. doi:10.15237/gida.GD19121

Özdemir, A., Demirel, Z. B. (2017). Beslenme ve Mikrobiyota ilişkisi. J Biotechnol and Strategic Health Res, 1: 25-33.

Potočnjak, M., Pušić, P., Frece, J., Abram, M., Janković, T., Gobin, I. (2017). Three new Lactobacillus plantarum strains in the probiotic toolbox against gut pathogen Salmonella enterica serotype Typhimurium. Food Technol Biotechnol, 55(1): 48-54. doi:10.17113/ftb.55.01.17.4693

Russo, P., Arena, M. P., Fiocco, D., Capozzi, V., Drider, D., Spano, G. (2017). Lactobacillus plantarum with broad antifungal activity: A promising approach to increase safety and shelflife of cereal-based products. Int J Food Microbiol, 247: 48-54.
Şanlier, N., Gökcen, B. B., Sezgin, A. C. (2019). Health benefits of fermented foods. Crit Rev Food Sci Nutr, 59(3): 506-527. doi: 10.1080/10408398.2017.1383355

Serra, D., Almeida, L. M., Dinis, T. C. (2019). The Impact of Chronic Intestinal Inflammation on Brain Disorders: the Microbiota-Gut-Brain Axis. Mol Neurobiol, 56(10):6941-6951. doi:10.1007/s12035-019-1572-8

Sugeçti, S., Büyükgüzel, E., Büyükgüzel, K. (2019). Barsak Mikrobiyotasının Nörodejeneratif Hastalıklar Üzerindeki Patofizyolojik Rolü. J Immunol Clin Microbiol, 4(4): 152-157.

Tamang, J., Watanabe, K., Holzapfel, W. (2016). Review: Diversity of microorganisms in global fermented foods and beverages. Front Microbiol, 7(337). doi:10.3389/fmicb.2016.00377

Tan, D. T., Poh, P. E., Chin, S. K. (2018). Microorganism preservation by convective airdrying-A review. Drying Technology, 36(7): 764-779. doi:10.1080/07373937.2017.1354876

Thursby, E., Juge, N. (2017). Introduction to the human gut microbiota. Biochem J, 474(11): 18231836. doi:10.1042/BCJ20160510

Tseng, C. H., Wu, C. Y. (2019). The gut microbiome in obesity. J Formosan Med Assoc, 118(1): S3-S9. doi:10.1016/j.jfma.2018.07.009

Tseng, W. T., Hsu, Y. W., Pan, T. M. (2016). The ameliorative effect of Monascus purpureus NTU 568-fermented rice extracts on 6hydroxydopamine-induced neurotoxicity in $\mathrm{SH}$ SY5Y cells and the rat model of Parkinson's disease. Food Funct, 7(2): 752-762. doi:10.1039/C5FO00976F

Vinicius De Melo Pereira, G., De Carvalho Neto, D. P., Junqueira, A. C. O., Karp, S. G., Letti, L. A., Magalhães Júnior, A. I., Soccol, C. R. (2019). A Review of Selection Criteria for Starter Culture Development in the Food Fermentation Industry. Food Rev Int, 1-33. doi:10.1080/87559129.2019.1630636

Vítor, J. M., Vale, F. F. (2011). Alternative therapies for Helicobacter pylori: probiotics and phytomedicine. FEMS Immunol Med Microbiol, 
63(2): $\quad$ 153-164. doi:10.1111/j.1574695X.2011.00865.x

Wong, C. B., Odamaki, T., Xiao, J. Z. (2019). Beneficial effects of Bifidobacterium longum subsp. longum BB536 on human health: Modulation of gut microbiome as the principal action. J Funct Foods, 54: 506-519. doi:10.1016/j.jff.2019.02.002

Yalçın, H., Üstündağ, H. (2017). Bacteriocins and their use in food products. MAKÜ Sag Bil Enst Derg, 5(1):

doi:10.24998/maeusabed.299346

53-65.

Zannini, E., Waters, D. M., Coffey, A., Arendt, E. K. (2016). Production, properties, and industrial food application of lactic acid bacteria-derived exopolysaccharides. Appl Microbiol Biotechnol, 100(3): 1121-1135. doi:10.1007/s00253-015$7172-2$

Zhao, W., Liu, Y., Latta, M., Ma, W., Wu, Z., Chen, P. (2019). Probiotics database: a potential source of fermented foods. Int J Food Prop, 22(1): 198-217. doi:10.1080/10942912.2019.1579737

Zhou, L., Foster, J. A. (2015). Psychobiotics and the gut-brain axis: in the pursuit of happiness. Neuropsychiatr Dis Treat, 11: 715-723. doi:10.2147/NDT.S61997 